\title{
Acute Exacerbation of
} Idiopathic Pulmonary Fibrosis with Lung Cancer:

A Comparative Analysis of the Incidence, Survival Rate, and CT Findings with the Patients without Lung Cancer

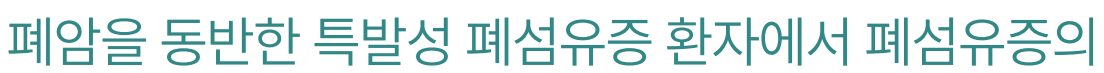

급성 악화:폐암 비동반군과의 발병률, 생존율 및

전산화단층찰영 소견의 비교

Bumsang Cho, $\mathrm{MD}^{1}\left(\mathbb{D}\right.$, Hee Kang, $\mathrm{MD}^{1^{\star}} \mathbb{( D}$, Je Hun Kim, $\mathrm{MD}^{2}$ (iD), Jung Gu Park, MD ${ }^{1}$, Sekyoung Park, MD ${ }^{1}$ iD, Jong Hyouk Yun, MD ${ }^{1}$

Departments of ${ }^{1}$ Radiology, ${ }^{2}$ Pulmonary and Critical Care Medicine, Kosin University Gospel Hospital, Kosin University College of Medicine, Busan, Korea

Purpose To compare the incidence, survival rate, and CT findings of acute exacerbation (AE) of idiopathic pulmonary fibrosis (IPF) between patients with and without lung cancer.

Materials and Methods From June 2004 to July 2018, 89 consecutive patients diagnosed with IPF were included. Among them, 26 patients had IPF with lung cancer (IPF-LCA), and 63 patients had IPF alone. The clinical characteristics and CT findings associated with IPF, lung cancer, and AE were reviewed. Surgery and chemotherapy were performed for 6 and 23 cases of lung cancer, respectively, as the first- or second-line anticancer treatment. The overall survival, $\mathrm{CT}$ findings, disease-free period before $\mathrm{AE}$, and duration from the onset of $\mathrm{AE}$ to death were compared.

Results The incidence of AE was $61.5 \%$ in the IPF-LCA group and $58.7 \%$ in the IPF group $(p=0.806)$. The mean overall survival in the IPF-LCA and IPF groups were 16.8 and 83.0 months, respectively $(p<0.001)$. The mean durations from the start of the lung cancer treatment to the onset of AE were 16.0 and 4.6 months in cases of surgical treatment and chemotherapy, respectively. In comparison of death from AE, the survival rate was significantly lower in the IPF-LCA group than in the IPF group $(p=0.008)$. In the CT findings associated with AE, the IPF-LCA group tended to have a peribronchial $(p<0.001)$ or asymmetric distribution $(p=0.016)$.
Received May 28, 2019

Revised August 14, 2019

Accepted September 3, 2019

${ }^{\star}$ Corresponding author Hee Kang, MD Department of Radiology, Kosin University Gospel Hospital, Kosin University College of Medicine, 262 Gamcheon-ro, Seo-gu, Busan 49267, Korea.

Tel 82-51-990-6341

Fax 82-51-255-2764

E-mail kanghi81@gmail.com

This is an Open Access article distributed under the terms of the Creative Commons Attribution Non-Commercial License (https://creativecommons.org/ licenses/by-nc/4.0) which permits unrestricted non-commercial use, distribution, and reproduction in any medium, provided the original work is properly cited.

\section{ORCID iDs}

Bumsang Cho (i)

https://

orcid.org/0000-0002-0588-1957

Hee Kang (D)

https://

orcid.org/0000-0001-8065-5477

Je Hun Kim (D)

https://

orcid.org/0000-0002-2594-0256

Jung Gu Park (D)

https://

orcid.org/0000-0002-1229-5745

Sekyoung Park (1)

https://

orcid.org/0000-0002-4616-3417

Jong Hyouk Yun (D)

https://

orcid.org/0000-0003-4890-4212 
Conclusion In patients with IPF who develop lung cancer, the rate of death from AE is higher than that in patients with IPF alone. They tend to have unusual CT patterns associated with AE, such as a peribronchial or asymmetric distribution.

Index terms Idiopathic Pulmonary Fibrosis; Lung Neoplasm; Usual Interstitial Pneumonia; Mortality

\section{INTRODUCTION}

Idiopathic pulmonary fibrosis (IPF) is the most common and fatal type of idiopathic interstitial pneumonia. It is defined as a specific form of chronic fibrosing interstitial pneumonia of unknown cause and is associated with the histopathologic pattern of usual interstitial pneumonia (UIP) $(1,2)$. In most cases, IPF progresses relatively slowly, and acute lesions of varying degrees can be seen without specific causes. If a cause of this deterioration cannot be identified, this deterioration is termed an acute exacerbation (AE) of IPF. The 1- to 3-year incidence of AE was reported at 14-20\% (3). High-resolution CT reveals new ground-glass abnormalities or consolidation superimposed on the reticular or honeycomb abnormalities typical of UIP. Lung pathology in AE is characterized by a combination of underlying UIP patterns associated with diffuse alveolar damage or organizing pneumonia features (4). AE is associated with poor outcomes and acute deterioration in IPF, and preceded death in $47 \%$ of deaths in a previous study (5). The risk factors of $\mathrm{AE}$ are unknown infection, smoking, and pulmonary hypertension (6-8). It has also been recently observed that $\mathrm{AE}$ develops in lung cancer patients after thoracic surgery and chemotherapy (9).

The previous literature reported there is significant difference in the survival time between IPF and IPF developing lung cancer patients. A shorter survival time is associated with the progression of lung cancer, as well as complications related to the diagnosis or treatment of lung cancer (9-11). To our knowledge, there has not yet been a study comparing the occurrence of AE and its mortality between the IPF patient with or without lung cancer.

The aim of our study was to compare the incidence and mortality of AE between IPF patients with and without lung cancer and to investigate whether there are differences in CT findings.

\section{MATERIALS AND METHODS}

\section{PATIENTS AND DATA COLLECTION}

Institutional Review Board approval was obtained for this retrospective study, and informed consent was waived (IRB No. 2018-08-025). Patients who were given a diagnosis of IPF on the basis of CT and clinical characteristics or histopathological confirmation were included between June 2004 and July 2018. The patient database in this institution revealed 150 patients who satisfied the diagnostic criteria for UIP. Among them, 41 cases were excluded because they did not have a follow-up CT scan. Also, 8 patients with connective tissue diseaserelated interstitial lung disease, 2 patients with asbestosis-related pulmonary fibrosis, and 10 
patients who were not confirmed for lung cancer were excluded. Patients were divided into IPF with lung cancer (IPF-LCA) and IPF without lung cancer (IPF) groups. The medical records including age, sex, smoking history, results of pulmonary function test (PFT), survival period, onset/period of AE, cause of death, and CT imaging findings were reviewed.

\section{IMAGE ACQUISITION}

The chest CT images were obtained at the time of the first diagnosis for IPF and onset of AE and the CT images were also obtained at the time of first diagnosis for lung cancer in the IPFLCA group. CT scans were acquired using a multi-detector CT system (Somatom Sensation 64 or dual-source Flash 128 multi-detector CT system, Siemens Medical Solutions, Erlangen, Germany). Scanning was performed from the lower part of the neck to the level of the middle portion of the kidneys. Intravenous contrast medium injection was used in a part of patients including IPF-LCA. An amount of $1.5 \mathrm{~mL} / \mathrm{kg}$ (body weight) of Iomeron 300 (Somatom Sensation 64 or dual-source Flash 128 multi-detector CT system) was injected at an infusion rate of $3 \mathrm{~mL} / \mathrm{s}$ using a power injector (Mallinckrodt, Tyco and Vistron CT, Medrad, Warrendale, PA, USA). The CT images were obtained with the following parameters: detector collimation 1.25 or $0.625 \mathrm{~mm}$; field of view, $36 \mathrm{~cm}$; 100 or $120 \mathrm{kVp}$; 90 to $200 \mathrm{~mA}$; tube rotation time, $0.5 \mathrm{~s}$; pitch, 1.2; and the reconstruction interval, 1 to $2.5 \mathrm{~mm}$. CT data were reconstructed using a highspatial-frequency algorithm for lung window images and by using a soft-tissue algorithm for mediastinal window images. On the monitors, both the mediastinal [window width, 400 Hounsfield unit (H); window level, $20 \mathrm{H}$ ] and lung (window width, $1500 \mathrm{H}$; window level, -700 H) window images were available for analysis.

\section{DIAGNOSIS OF IPF}

IPF was diagnosed according to the 2018 consensus of the American Thoracic Society, the European Respiratory Society, the Japanese Respiratory Society, and the Latin American Thoracic Association $(1,12)$. UIP defined on chest CT by the presence of subpleural, base predominance, reticular abnormality, honeycombing with or without peripheral traction bronchiectasis or bronchiolectasis. We declared IPF when there was a pattern of UIP on CT. In cases of probable UIP or indeterminate with UIP on CT, IPF was diagnosed through multidisciplinary considerations including clinical and pathological results.

The pathologic diagnosis of UIP included dense fibrosis, which causes remodeling of lung architecture with frequent honeycomb fibrosis; fibroblast foci, which are typically scattered at the edges of dense scars; patchy lung involvement; and frequent subpleural, paraseptal, and peripheral acinar distribution (13).

The other forms of interstitial lung disease such as domestic and occupational environmental exposures, connective tissue disease, and drug toxicity were excluded.

\section{EVALUATION OF LUNG CANCER}

In the IPF-LCA group, all lung cancers were pathologically determined through surgery, bronchoscopy, or percutaneous biopsy. The histological type of cancer, stage at the time of diagnosis, types of treatment, treatment response and causes of deaths were reviewed. Chest CT findings of lung cancer related to pulmonary fibrosis were also evaluated for lo- 
cation (peripheral/central, lobe) and background (fibrotic, abutting the fibrotic lung, normal lung).

\section{ACUTE EXACERBATION}

$\mathrm{AE}$ of IPF was diagnosed based on the criteria published from National Institutes of Healthsponsored IPF Clinical Trials Network. These criteria included a previous or concurrent diagnosis of IPF, acute worsening or development of dyspnea typically less than 1-month duration, CT findings of new bilateral ground-glass opacity, and/or consolidation superimposed on a background pattern consistent with UIP pattern, and deterioration not fully explained by cardiac failure or fluid overload. The other etiologies are also excluded including infection, pulmonary embolism, identifiable cause of acute lung injury (5). The CT findings for AE were classified and analyzed for parenchymal density (ground glass opacity and consolidation), interstitial density (reticulation and honeycombing), distribution (peribronchial, subpleural, diffuse, symmetric, and asymmetric), and additional findings of pleural effusion. The incidence, risk factors, disease-free period of $\mathrm{AE}$, and duration from onset of $\mathrm{AE}$ to death were also evaluated. The disease-free period of $\mathrm{AE}$ was defined as the period from diagnosis of IPF to the first event of AE. The duration from onset AE to death was a period from diagnosis of AE to death.

\section{STATISTICAL ANALYSIS}

Statistical analyses were conducted with SPSS software (SPSS version 19.0; IBM Corp., Armonk, NY, USA). Data were summarized and displayed as the mean ( \pm standard deviation) or the median for continuous variables and number of individuals plus the percentage in each group for categorical variables.

The incidence, overall survival, AE disease-free period, duration from onset of AE to death, and CT findings of AE were compared between the IPF and the IPF-LCA groups using a twosample rank-sum test for continuous variables, the $\chi^{2}$ test for categorical variables, and the Kaplan-Meier method for cumulative time-to-event distribution. A $p$-value $<0.5$ was considered statistically significant.

\section{RESULTS}

The clinical characteristics and PFT results for the patients at the time of initial IPF diagnosis are in Table 1. Eighty-nine consecutive patients consisted of 26 patients with IPF and biopsy-proven lung cancer (IPF-LCA) and 63 patients with IPF only (IPF). To compare baseline characteristics of the two groups, smoking habits, pack-years of smoking, forced vital capacity (FVC), combined pulmonary fibrosis, and emphysema (CPFE) were significantly higher and forced expiratory volume in 1 second (FEV1)/FVC was significantly lower in IPF-LCA than in IPF. There were no significant differences in age and sex.

Twenty-six patients were diagnosed lung cancer with IPF. The characteristics of lung cancer are in Table 2. The mean time between diagnosis of IPF and diagnosis of lung cancer was 6.5 months (range 0-48.3). The lung cancers consisted of 19 non-small cell carcinomas and seven small-cell carcinomas. Of the non-small cell carcinomas, adenocarcinoma was the 
Table 1. Clinical Characteristics of Patients with IPF and Lung Cancer and Patients with IPF Alone

\begin{tabular}{lccr}
\hline & IPF $(n=63)$ & IPF-LCA $(n=26)$ & $p$-Value \\
\hline Age, years & $68.95 \pm 8.4$ & $66.58 \pm 8.0$ & 0.226 \\
Male (female), \% of male & $49(14), 74.2$ & $22(4), 84.6$ & 0.471 \\
Smoker & $36(57.1)$ & $26(100)$ & $<0.001$ \\
$\quad$ Current & $8(13)$ & $20(77)$ & \\
Past & $28(44)$ & $6(23)$ & \\
$\quad$ Never & $27(43)$ & $0(0)$ & 0.004 \\
Pack-year, years & $20.15 \pm 25.8$ & $36.98 \pm 14.6$ & 0.009 \\
FVC & $2.47 \pm 0.8$ & $2.94 \pm 0.6$ & 0.002 \\
FEV1/FVC & $82.08 \pm 7.6$ & $75.80 \pm 8.3$ & $<0.001$ \\
CPFE & $9(14)$ & $21(80)$ & \\
\hline
\end{tabular}

Data are mean \pm standard deviation or $n(\%)$ values.

$\mathrm{CPFE}=$ combined pulmonary fibrosis and emphysema, FEV1 = forced expiratory volume in 1 second, FVC = forced vital capacity, IPF-LCA = idiopathic pulmonary fibrosis with lung cancer

Table 2. Characteristics of Lung Cancer in Patients with Idiopathic Pulmonary Fibrosis

\begin{tabular}{|c|c|}
\hline \multicolumn{2}{|c|}{ Characteristics } \\
\hline \multicolumn{2}{|l|}{ Location } \\
\hline Peripheral (central) & $21(5)$ \\
\hline Upper lobes (lower lobes) & $11(15)$ \\
\hline \multicolumn{2}{|l|}{ Background of lung cancer } \\
\hline Fibrotic background & 16 \\
\hline Abutting the fibrotic lung & 8 \\
\hline Normal lung & 2 \\
\hline \multicolumn{2}{|l|}{ Histologic type } \\
\hline$A D C$ & 10 \\
\hline SQCC & 7 \\
\hline Combined ADC \& SQCC & 2 \\
\hline Small cell lung cancer & 7 \\
\hline \multicolumn{2}{|l|}{ Stage of lung cancer } \\
\hline \multicolumn{2}{|l|}{ Non-small cell lung cancer } \\
\hline I & 4 \\
\hline$\|$ & 2 \\
\hline III & 6 \\
\hline IV & 7 \\
\hline \multicolumn{2}{|l|}{ Small cell lung cancer } \\
\hline Limited stage & 1 \\
\hline Extensive stage & 6 \\
\hline \multicolumn{2}{|l|}{ Treatment of lung cancer } \\
\hline Surgery & $6(17)$ \\
\hline Chemotherapy & $23(66)$ \\
\hline Radiation therapy & $3(8)$ \\
\hline Gene target therapy & $3(8)$ \\
\hline \multicolumn{2}{|l|}{ Causes of death of lung cancer } \\
\hline Respiratory failure due to $\mathrm{AE}$ & $10(58)$ \\
\hline Lung cancer progression & $4(24)$ \\
\hline Others including infection or heart disease & $3(18)$ \\
\hline
\end{tabular}

Data are $n$ or $n(\%)$ values.

$\mathrm{ADC}=$ adenocarcinoma, $\mathrm{AE}=$ acute exacerbation, $\mathrm{SQCC}=$ squamous cell carcinoma 
Fig. 1. Disease-free period before AE in the IPF-LCA group and the IPF group $(p=0.002)$.

$\mathrm{AE}=$ acute exacerbation, IPF-LCA = idiopathic pulmonary fibrosis with lung cancer

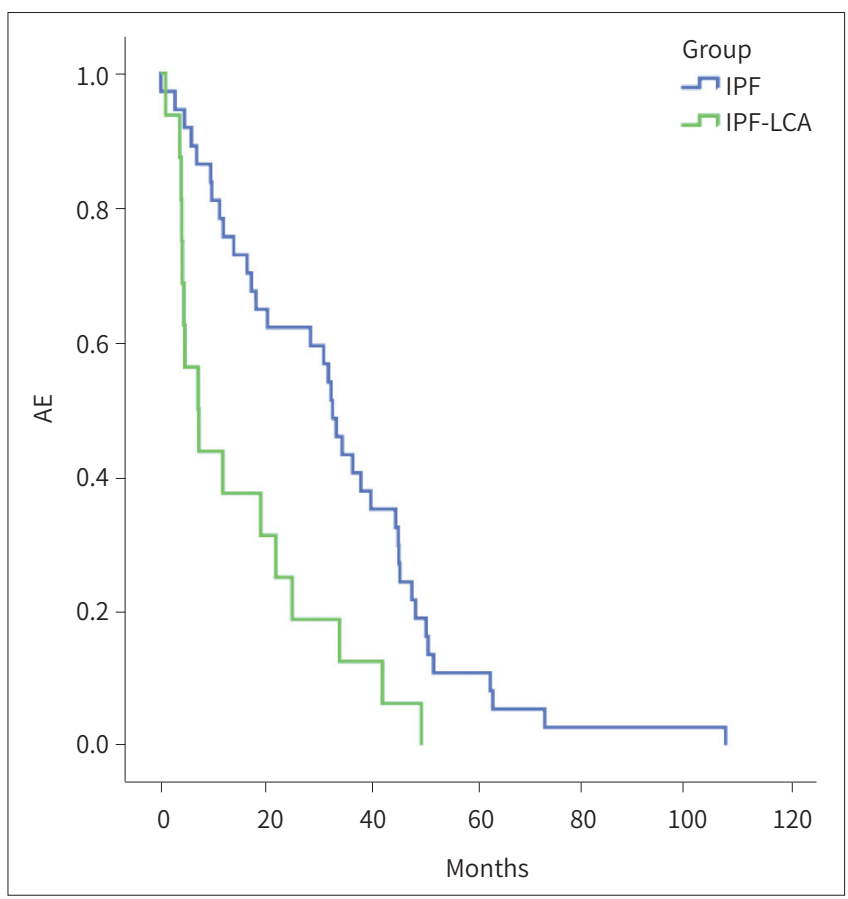

most frequent cell type $(n=10)$, followed by squamous-cell carcinoma $(n=7)$, and two cases had a combined type. The location of lung cancer was peripheral, $n=21$; central, $n=5$; upper lobes, $n=11$; and lower lobe, $n=15$. The fibrotic background was the most frequent background of lung cancer $(n=16)$, followed by abutting the fibrotic lung $(n=8)$, and two cases were normal lung. Lung cancer patients underwent surgery in 6 cases, chemotherapy in 23 cases, radiation therapy in 3 cases, and gene target therapy in 3 cases as the first- or second-line anticancer treatment. The causes of death in lung cancer patients were respiratory failure due to $\mathrm{AE}(n=10,58.8 \%)$, lung cancer progression $(n=4,23.5 \%)$, and others including infection or heart disease $(n=3,17.6 \%)$.

The incidence of AE was 59.5\% among all IPF patients. AE occurred in 37 patients (58.7\%) in the IPF group and 16 patients (61.5\%) in the IPF-LCA group. In one patient, AE occurred at the same time for the diagnosis of IPF. There was no significant difference between the two groups with respect to occurrence of $\mathrm{AE}(p=0.806)$. However, the disease-free period of AE between the two groups was significantly different $(p=0.002)$ (Fig. 1). The mean AE diseasefree period was 33.0 months (range 0.0-107.5) in the IPF group and 15.2 months (range 0.949.6) in the IPF-LCA group. The duration from onset of AE to death between the IPF group and the IPF-LCA group was also significantly different $(p=0.013$ ) (Fig. 2). The mean duration from onset of AE to death was 6.5 months (range 0.1-44.4) in the IPF group and 0.5 months (range 0.1-1.1) in the IPF-LCA group. The mean duration from start of lung cancer treatment to onset of AE was 6.4 months (range 0.4-24.6). The mean duration was 16.0 months (range 2.8-24.6) in surgical treatment, 4.6 months (range 0.4-7.5) in chemotherapy, 4.0 month (range 1.7-6.4) in radiation therapy, and 0.9 months in gene therapy. The CT findings for AE in the IPF-LCA and IPF groups are presented in Table 3. Peribronchial distribution $(p<0.001)$ and pleural effusion $(p=0.003)$ were more common in the IPF-LCA group (Figs. 3 , 4). In- 


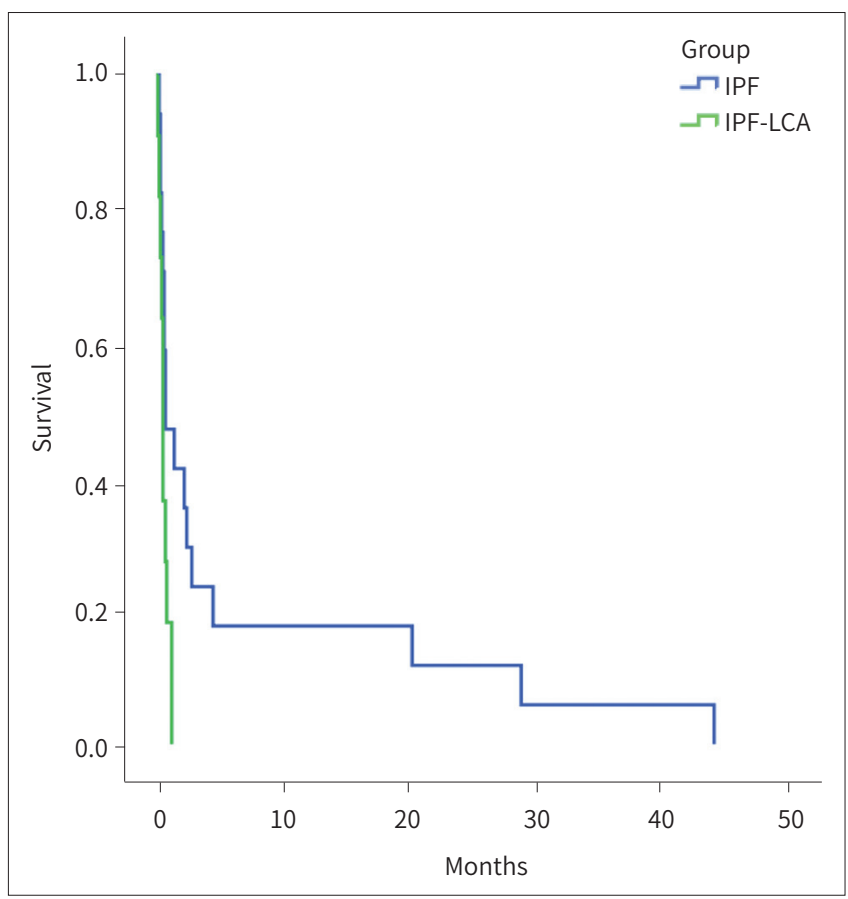

Fig. 2. Duration from the onset of acute exacerbation to death in the IPF-LCA group and the IPF group $(p=$ 0.013).

IPF-LCA = idiopathic pulmonary fibrosis with lung cancer

Table 3. Statistical Comparison of the Frequency of CT Findings Associated with Acute Exacerbation between Patients with IPF and Lung Cancer and Patients with IPF Alone

\begin{tabular}{lccc}
\hline \multicolumn{1}{c}{ Findings } & IPF $(n=37, \%)$ & IPF-LCA $(n=16, \%)$ & p-Value \\
\hline Opacity & & & \\
Ground glass opacity & $37(59)$ & $16(100)$ & - \\
Consolidation & $19(51)$ & $9(56)$ & 0.817 \\
Increase of reticulation & $37(100)$ & $14(88)$ & 0.156 \\
Increase of honeycombing & $21(57)$ & $4(25)$ & 0.026 \\
Distribution & & & \\
Peribronchial & $2(5)$ & $9(56)$ & 0.001 \\
Subpleural & $7(19)$ & $7(44)$ & 0.060 \\
$\quad$ Diffuse & $30(81)$ & $7(44)$ & 0.013 \\
$\quad$ Symmetric & $32(86)$ & $9(56)$ & 0.016 \\
Additional finding & $1(3)$ & & 0.003 \\
\hline Pleural effusion & & $5(31)$ & \\
\hline
\end{tabular}

IPF-LCA = idiopathic pulmonary fibrosis with lung cancer

crease of honeycombing $(p=0.026)$, symmetric distribution $(p=0.016)$, and diffuse $(p=0.013)$ distribution were more common in the IPF group. There is no significant difference between the two groups with respect to increase of ground glass opacity, consolidation or reticulation, and subpleural distribution.

The mean overall survival was 67.4 months (median 49.1, range 0.9-148.4) among all the IPF patients. The overall survival was significantly different between the IPF-LCA group and the IPF group ( $p<0.001$ ). The mean survival was 80.4 months (median 83.0, range 1.3-148.4) in the IPF group and 28.0 months (median 16.8, range 0.9-76.4) in the IPF-LCA group. The significant risk factors affect- 
Fig. 3. A 67-year-old male with idiopathic pulmonary fibrosis and lung adenocarcinoma who underwent chemotherapy.

A. Axial CT in the lung window at the level of the carina shows peribronchial and subpleural ground glass opacities and consolidation in the left hemithorax (black arrow).

B. Axial CT in the lung window at the level of the aortic root shows an asymmetric distribution of subpleural ground glass opacities in the left hemithorax (black arrow). Primary lung cancer is seen in the right lower lobe (asterisk). A small amount of pleural effusion is also noted (empty arrow). The patient was administered with antibiotics and corticosteroids but died 11 days after the onset of acute exacerbation.
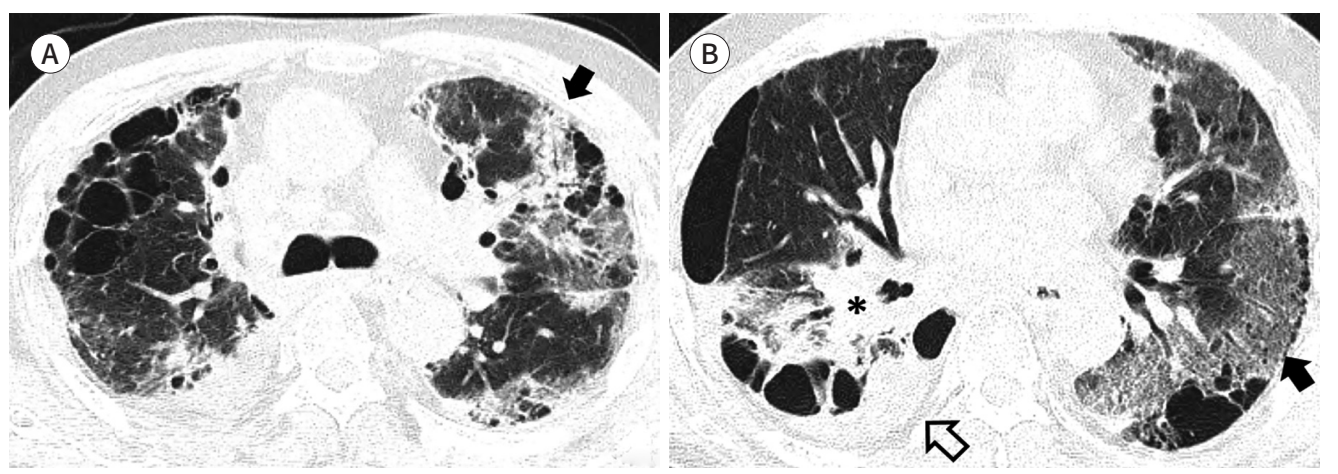

Fig. 4. A 55-year-old male with idiopathic pulmonary fibrosis and lung adenocarcinoma who underwent chemotherapy.

Axial CT in the lung window at the level of the aortic root shows asymmetric diffuse ground glass opacities (black arrow) in the right hemithorax with underlying subpleural honeycombing (arrowhead). Multiple lungto-lung metastatic nodules are seen in the left hemithorax (empty arrows). The patient was administered with corticosteroids but died 10 days after the onset of acute exacerbation.

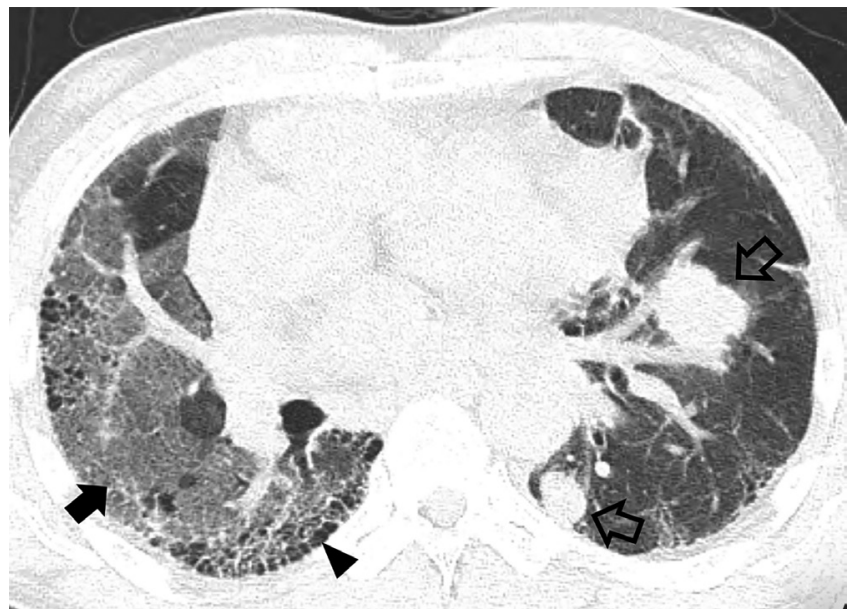

ing mortality were lung cancer [odds ratio $(\mathrm{OR})=3.8, p=0.001$ ] and $\mathrm{AE}(\mathrm{OR}=2.4, p<0.001)$.

Although $\mathrm{AE}$ is a significant risk factor affecting death in both IPF-LCA and IPF groups, in the aspect of death by AE, the survival rate of IPF-LCA was significantly lower than that of IPF group ( $p=0.008$ ). The mean survival was 39.5 months (median 39.2, range 1.3-107.7) who died by AE in IPF group and 13.5 months (median 7.5, 4.2-34.0) who died by AE in IPF-LCA group (Fig. 5).

\section{DISCUSSION}

IPF is a kind of idiopathic interstitial pneumonia with a progressive disease course and poor prognosis. It has the histologic finding of UIP characterized by two key features: spatial heterogeneity, which refers to a patchy distribution of dense parenchymal scarring alternating with normal parenchyma, and temporal heterogeneity, which refers to areas of densely 


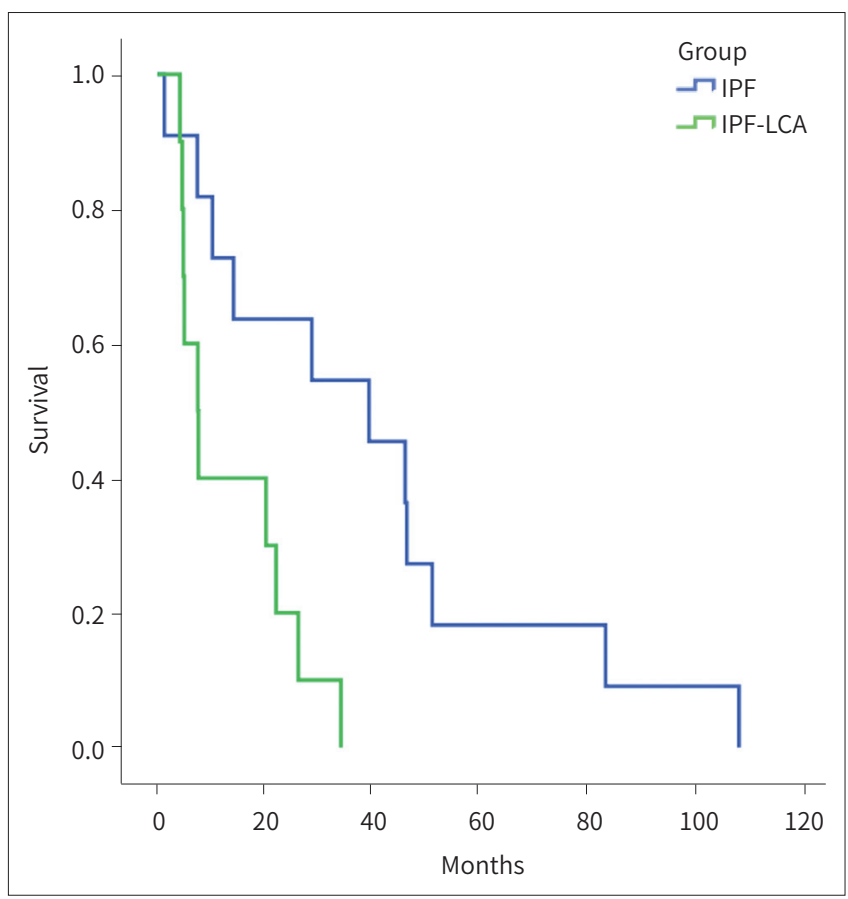

Fig. 5. Survival curves of the IPF-LCA and IPF groups for death from acute exacerbation $(p=0.008)$. IPF-LCA = idiopathic pulmonary fibrosis with lung cancer

collagenized fibrosis (the past) alternating with active fibroblast foci (the present) (14).

It is well known that patients with IPF are at high risk for lung cancer. Ozawa et al. (14) reported the cumulative incidence of lung cancer in IPF increased markedly over time, with rates of $3.3 \%, 15.4 \%$, and $54.7 \%$ at 1,5 , and 10 years, respectively. In another report by Tomassetti et al. (8), the cumulative incidence of lung cancer in IPF was $41 \%$ and $82 \%$ at 1 and 3 years, respectively. Age and smoking status have also been identified as risk factors for lung cancer development in patients with IPF (10).

In our study, the incidence of lung cancer in patients with IPF was 29.2\%. It was relatively higher compared to previous studies. This result is thought to stem from differences between cohorts, as ours was from a tertiary cancer-specialized hospital.

Though adenocarcinoma is the most common histologic type of lung cancer in the general population (15), the most frequently represented type in patients with IPF was squamous cell carcinoma followed by adenocarcinoma $(9,10)$. In a study by Kawasaki et al. (15), the frequency of histologic types of squamous cell carcinoma and adenocarcinoma were same. In our study, although adenocarcinoma was the most frequent type $(n=10)$ followed by squamous cell carcinoma $(n=7)$, the difference in frequency was not great. This may be due to the small sample size and the higher incidence of lung adenocarcinoma diagnosis in East Asia.

The distribution of lung cancer in patients with IPF demonstrated that most tumors were localized in more peripheral fibrotic areas of the lung compared with the general population $(9,10,16)$. In our study, the location of lung cancer also showed a tendency of peripheral, lower lobes and fibrotic background. This has been explained by a mechanism similar to "scar cancer;" there is a hypothesis that the accumulation of carcinogenic factors in the epithelium is increased due to lymphatic obstruction by fibrosis or the epithelium shows abnormal proliferation or hyperplasia between normal lung parenchyma and the transition zone $(17,18)$. 
AEs of IPF are lethal events in the natural history of IPF. The incidence of AE was highly variable among different studies, ranging from 4.8-43\% (3, 19, 20). The lack of a standardized definition of $\mathrm{AE}$ and different study designs played a major role in the variability of frequencies reported. Our result showed a high incidence of AE (59.2\%) with a median of a 33.9-month follow-up period, likely because our institution is a tertiary hospital and there are many serious cases. The risk factors reported in the literature for development of $\mathrm{AE}$ were thoracic surgery, low FVC, and chemotherapy (3, 9, 12, 21, 22). The previous reported studies showed the overall incidence of AE in patients with IPF undergoing resection for lung cancer to be significantly higher than in patients without pulmonary resection for lung cancer (12, 21). The triggers were considered to be prolonged ventilation at a large tidal volume with oxygen supplementation at a high concentration during the lung operation (12). Recent studies have reported the risk of diffuse lung injury by anti-cancer treatment such as chemotherapy, tyrosine kinase inhibitors, and immune-checkpoint inhibitor therapy. They can alter epithelial cell function, triggering fibrogenesis and causing alveolar and bronchial epithelial injuries followed by diffuse alveolar damage with hyaline membrane formation (23, 24).

Diagnosis of AE in patients with IPF is important because AE affects the survival rate and life quality of IPF patients. Akira et al. $(25,26)$ reported CT findings in AE of IPF. They defined CT patterns of AE as peripheral, multifocal, or diffuse. Peripheral distribution was most common in AE in their study followed by diffuse and multifocal distributions. In our study, peribronchial and asymmetric distribution of parenchymal opacity for CT finding of AE was more common in IPF patients with lung cancer. The IPF patients without lung cancer exhibited a diffuse distribution more frequently. Although this may be caused by early detection of lung lesions in patients undergoing lung cancer follow-up, awareness of these unusual features may be helpful in the diagnosis of AE in IPF patients with lung cancer.

The survival rate was significantly different between IPF and IPF-LCA patients in our study, which is consistent with the previously reported survival rates for IPF and IPF-LCA (9-11). Tomassetti et al. (8) compared the IPF patients with and without LCA and showed a median survival of 63.9 months and 38.7 months, and we observed a median survival of 83.0 months and 16.8 months, respectively, which is a slightly longer survival for IPF-only patients and shorter survival for IPF-LCA patients in our study. In terms of the causes of death in IPF-LCA patients, the most common cause was the progression of pulmonary fibrosis, not the cancer itself. Thus, controlling both pulmonary fibrosis and the lung cancer are important to prolong survival.

There were several limitations in this study. First, it was a retrospective study performed at a single cancer-specialized institution, so there could have been selection and verification biases. Therefore, a prospective multicenter study is warranted to verify our findings. Second, this study has a small sample size of patients with IPF and lung cancer. An additional prospective study with a larger number of cases may be necessary to verify our hypothesis. Third, AE of IPF was not diagnosed pathologically.

In conclusion, in patients with IPF who are developing lung cancer, mortality by AE is higher than in patients with IPF only. They tend to have CT patterns of peribronchial or asymmetric distributions for the initial manifestation of AE. Awareness of these CT patterns may be helpful in the prompt and appropriate management of AE in IPF patients with lung cancer and contribute to prolong their survival. 


\section{Author Contributions}

Conceptualization, K.H.; data curation, K.J.H.; formal analysis, K.H., P.S.; investigation, C.B., K.H.; methodology, K.H.; project administration, K.H., Y.J.H.; resources, K.J.H., K.H.; supervision, P.J.G.; and writing-original draft, C.B., K.H.

\section{Conflicts of Interest}

The authors have no potential conflicts of interest to disclose.

\section{REFERENCES}

1. Raghu G, Collard HR, Egan JJ, Martinez FJ, Behr J, Brown KK, et al. An official ATS/ERS/JRS/ALAT statement: idiopathic pulmonary fibrosis: evidence-based guidelines for diagnosis and management. Am J Respir Crit Care Med 2011;183:788-824

2. No authors listed. American Thoracic Society. Idiopathic pulmonary fibrosis: diagnosis and treatment. International consensus statement. American Thoracic Society (ATS), and the European Respiratory Society (ERS). Am J Respir Crit Care Med 2000;161:646-664

3. Song JW, Hong SB, Lim CM, Koh Y, Kim DS. Acute exacerbation of idiopathic pulmonary fibrosis: incidence, risk factors and outcome. Eur Respir J 2011;37:356-363

4. Churg A, Müller NL, Silva Cl, Wright JL. Acute exacerbation (acute lung injury of unknown cause) in UIP and other forms of fibrotic interstitial pneumonias. Am J Surg Pathol 2007;31:277-284

5. Collard HR, Moore BB, Flaherty KR, Brown KK, Kaner RJ, King TE Jr, et al. Acute exacerbations of idiopathic pulmonary fibrosis. Am J Respir Crit Care Med 2007;176:636-643

6. Antoniou KM, Wells AU. Acute exacerbations of idiopathic pulmonary fibrosis. Respiration 2013;86:265-274

7. Kim DS. Acute exacerbations in patients with idiopathic pulmonary fibrosis. Respir Res 2013;14:86

8. Tomassetti S, Gurioli C, Ryu JH, Decker PA, Ravaglia C, Tantalocco P, et al. The impact of lung cancer on survival of idiopathic pulmonary fibrosis. Chest 2015;147:157-164

9. Lee T, Park JY, Lee HY, Cho YJ, Yoon HI, Lee JH, et al. Lung cancer in patients with idiopathic pulmonary fibrosis: clinical characteristics and impact on survival. Respir Med 2014;108:1549-1555

10. Saito Y, Kawai Y, Takahashi N, Ikeya T, Murai K, Kawabata Y, et al. Survival after surgery for pathologic stage IA non-small cell lung cancer associated with idiopathic pulmonary fibrosis. Ann Thorac Surg 2011;92:1812-1817

11. Lynch DA, Sverzellati N, Travis WD, Brown KK, Colby TV, Galvin JR, et al. Diagnostic criteria for idiopathic pulmonary fibrosis: a Fleischner Society White Paper. Lancet Respir Med 2018;6:138-153

12. Collard HR, Ryerson CJ, Corte TJ, Jenkins G, Kondoh Y, Lederer DJ, et al. Acute exacerbation of idiopathic pulmonary fibrosis. An International Working Group Report. Am J Respir Crit Care Med 2016;194:265-275

13. Nishimura K, Kitaichi M, Izumi T, Nagai S, Kanaoka M, Itoh H. Usual interstitial pneumonia: histologic correlation with high-resolution CT. Radiology 1992;182:337-342

14. Ozawa Y, Suda T, Naito T, Enomoto N, Hashimoto D, Fujisawa T, et al. Cumulative incidence of and predictive factors for lung cancer in IPF. Respirology 2009;14:723-728

15. Kawasaki H, Nagai K, Yokose T, Yoshida J, Nishimura M, Takahashi K, et al. Clinicopathological characteristics of surgically resected lung cancer associated with idiopathic pulmonary fibrosis. J Surg Oncol 2001;76:53-57

16. Dela Cruz CS, Tanoue LT, Matthay RA. Lung cancer: epidemiology, etiology, and prevention. Clin Chest Med 2011;32:605-644

17. Horowitz JC, Osterholzer JJ, Marazioti A, Stathopoulos GT. "Scar-cinoma": viewing the fibrotic lung mesenchymal cell in the context of cancer biology. Eur Respir J 2016;47:1842-1854

18. Martinez FJ, Safrin S, Weycker D, Starko KM, Bradford WZ, King TE Jr, et al. The clinical course of patients with idiopathic pulmonary fibrosis. Ann Intern Med 2005;142:963-967

19. Sugino K, Nakamura Y, Ito T, Isshiki T, Sakamoto S, Homma S. Comparison of clinical characteristics and outcomes between combined pulmonary fibrosis and emphysema associated with usual interstitial pneumonia pattern and non-usual interstitial pneumonia. Sarcoidosis Vasc Diffuse Lung Dis 2015;32:129-137

20. Sakamoto S, Homma S, Mun M, Fujii T, Kurosaki A, Yoshimura K. Acute exacerbation of idiopathic interstitial pneumonia following lung surgery in 3 of 68 consecutive patients: a retrospective study. Intern Med 2011;50:77-85 
21. Kumar P, Goldstraw P, Yamada K, Nicholson AG, Wells AU, Hansell DM, et al. Pulmonary fibrosis and lung cancer: risk and benefit analysis of pulmonary resection. J Thorac Cardiovasc Surg 2003;125:1321-1327

22. Isobe K, Hata Y, Sakamoto S, Takai Y, Shibuya K, Homma S. Clinical characteristics of acute respiratory deterioration in pulmonary fibrosis associated with lung cancer following anti-cancer therapy. Respirology 2010;15:88-92

23. Min JH, Lee HY, Lim H, Ahn MJ, Park K, Chung MP, et al. Drug-induced interstitial lung disease in tyrosine kinase inhibitor therapy for non-small cell lung cancer: a review on current insight. Cancer Chemother Pharmacol 2011;68:1099-1109

24. Suzuki H, Aoshiba K, Yokohori N, Nagai A. Epidermal growth factor receptor tyrosine kinase inhibition augments a murine model of pulmonary fibrosis. Cancer Res 2003;63:5054-5059

25. Akira M, Kozuka T, Yamamoto S, Sakatani M. Computed tomography findings in acute exacerbation of idiopathic pulmonary fibrosis. Am J Respir Crit Care Med 2008;178:372-378

26. Akira M, Hamada H, Sakatani M, Kobayashi C, Nishioka M, Yamamoto S. CT findings during phase of accelerated deterioration in patients with idiopathic pulmonary fibrosis. AJR Am J Roentgenol 1997;168:79-83 
암을 동반한 특발성 폐섬유증 환자에서 폐섬유증의 급성 악화: 폐암 비동반군과의 발병률, 생존율 및 전산화단층촬영 소견의 비교

조범상 $\cdot$ 강 희 $^{*} \cdot$ 김제훈 ${ }^{2} \cdot$ 박정구 $^{1} \cdot$ 박세경 1 윤종혁1

목적 폐암이 동반된 특발성 폐섬유증 환자와 폐암 비동반 특발성 폐섬유증 환자에서 폐섬유 증 급성 악화의 발병률, 생존율 및 전산화단층촬영 소견을 비교하고자 하였다.

대상과 방법 2004년 6월부터 2018년 7월까지, 특발성 폐섬유증으로 진단받은 89명의 환자를 대상으로 하였으며 26 명의 폐암 동반 특별 폐섬유증 환자군과 63 명의 폐암 비동반 특발 폐섬 유증 환자군으로 구성되었다. 이들의 폐섬유증, 폐암, 급성 악화와 관련된 임상 검사 소견과 CT 소견을 검토하였다. 폐암 환자들은 1 차 또는 2차 치료로 수술 $(n=6)$, 항암치료 $(n=23)$ 등 을 받았다. 두 군 간에 생존율, 급성 악화의 CT 소견, 무병 기간과 급성 악화 발병 이후 사망 까지의 시간을 비교하였다.

결과 급성 악화의 발병률은 폐암 동반군에서는 $61.5 \%$, 비동반군에서는 $58.7 \%$ 였다( $p=0.806)$. 폐암 동반군과 비동반군의 평균 생존 기간은 각각 16.8 개월과 83.0 개월이었다 $(p<0.001)$. 치 료 시작부터 급성 악화까지의 기간은 수술과 항암치료에서 각각 16.0 개월과 4.6 개월이었다. 급성 악화에 의한 사망을 비교하였을 때, 생존율은 폐암 동반군이 비동반군보다 유의하게 낮 았다 $(p=0.008)$. 급성 악화의 CT 소견은 폐암 동반군에서 기관지 주위 분포 $(p<0.001)$ 와 비대 칭 분포 $(p=0.016)$ 를 보이는 경우가 많았다.

결론 폐암을 동반한 특발성 폐섬유증 환자에서, 급성 악화에 의한 사망률이 폐암 비동반 특발 폐섬유증 환자들보다 높았다. 또한, 기관지 주위 또는 비대칭 분포의 CT 소견을 보이는 경향 이 있다. 